AL-URBAN: Jurnal Ekonomi Syariah dan Filantropi Islam

Vol. 3, No. 2, Desember 2019

http://journal.uhamka.ac.id/index.php/al-urban

p-ISSN: 2580-3360 e-ISSN: 2581-2874

DOI: $10.22236 /$ alurban_vol1/is1pp164-179

Hal 164-179

\title{
SIKAP, SUBYEKTIF NORMAL, DAN PENGENDALIAN DIRI UNTUK TERHADAP KINERJA AGEN PEMASARAN PRODUK HARTAL MART.
}

\author{
Ridwan $^{1}$, Achmad Firdaus ${ }^{2}$, Mokhamad Yasid ${ }^{3}$ \\ ${ }^{1,2,3}$ Institut Agama Islam Tazkia \\ achmad.firdaus@tazkia.ac.id
}

Diterima: 8 Oktober 2019; Direvisi: 23 November 2019; Disetujui: 21 Desember 2019

\begin{abstract}
The purpose of this study is to analyze the effect of attitude has a significant influence on agent intentions, the influence of subjective norms on agent intentions, the effect of self-control on agent intentions in marketing halal mart products. This study uses the Theory Planned Behavior method and structured equation modeling (SEM) to see the effect of agents on the intentions and performance of agents to market halalmart products through measurement in terms of attitudes, subjective norms and self-control. The results of the research data show that attitudes, subjective norms and self-control have a significant and positive influence on the intentions of the agents to improve performance in marketing halalmart products.
\end{abstract}

Keyword: agent, halalmart, Theory of Planned Behavior (TPB), Structural Equation Modeling (SEM)

\footnotetext{
Abstrak

Tujuan dari penelitian ini adalah untuk menganalisis pengaruh sikap mempunyai pengaruh signifikan terhadap intensi agen, pengaruh norma subjektif terhadap intensi agen, pengaruh pengendalian diri terhadap intensi agen dalam memasarkan produk halal mart. Penelitian ini menggunakan metode Theory Planned Behavior dan structured equation modeling (SEM) untuk melihat pengaruh dari agen dalam intensi dan kinerja agen untuk memasrkan produk halalmart melalui pengukuran dalam hal sikap, norma subjektif dan pengendalian diri. Hasil data penelitian menunjukan bahwa Sikap, norma subjektif dan pengendalian diri mempunyai pengarh signifikadn dan positif terhadap intensi dari para agen untuk peningkatan kinerja dalam memasarkan produk halalmart.

Kata Kunci : Agen, Halalmart, Theory of Planned Behavior (TPB), Structural Equation Modeling (SEM)
} 


\section{PENDAHULUAN}

Berbisnis adalah salah satu sumber dalam mendapatkan penghasilan, Pemasaran merupakan salah satu bagian dari bisnis, dimana saat ini berbagai model pemasaran dilakukan agar bisnis mendapatkan profit dan bertumbuh. Salah satu metode pemasaran yang muncul di masyarakat adalah dengan menggunakan metode multi level marketing (MLM), Arum (2012) menjelaskan bisnis MLM mulai berkembang pada tahun 1940-an di Amerika, kemudian mengalami pertumbuhan dengan cepat di seluruh penjuru Indonesia dengan berbagai bentuknya. Dalam perkembangannya terbagi menjadi dua yakni MLM murni, yaitu bisnis yang berbasis omset dan Money Game berkedok MLM dimana dalam mendapatkan bonus yang bertumbuh dengan mengandalkan hasil dari rekrutmerekrut anggota. Mereka dibayar berdasarkan jumlah banyaknya hasil rekrutmen dan keseimbangan jaringan. Bisnis semacam ini biasanya menggunakan sistem dua kaki (skema ponzi)/skema piramida yang sudah banyak dilarang di berbagai negara. Bisnis ini biasa disebut dengan bisnis money game yang sering berkedok sebagai MLM. Komara (2018) mengungkapkan ada sekitar 14 juta penduduk Indonesia yang terlibat dalam bisnis direct selling dengan model Network Marketing/MLM dan tercatat membukukan Omzet sebesar Rp 15,75 Triliun. Ada sekitar 600 perusahaan penjualan langsung berjenjang yang beroperasi di Indonesia dimana 85 perusahaan diantaranya adalah legal dan sudah resmi menjadi anggota APLI/ Asosiasi Penjualan Langsung Indonesia sebagai wadah resmi perusahaan penjualan langsung berjenjang di Indonesia. Kurang lebih 20\% merupakan perusahaan asing dan sekitar $80 \%$ merupakan perusahaan lokal Indonesia.

Permasalahan yang muncul di masyarakat dan mengganggu perkembangan industri MLM adalah maraknya bisnis money game yang berkedok MLM. Umat Islam di Indonesia merupakan agama mayoritas penduduknya Indonesia, dimana muslim menurut sensus BPS (2010) berjumlah 87,2\% namun dalam tataran realitanya perusahaan MLM yang mendapatkan sertifikasi Syari'ah tidak mengalami kenaikan yang signifikan.

Dibawah ini merupakan gambar perbandingan dalam skala Industri, perusahaan yang sudah legal terdaftar di APLI dan perusahaan yang mendapatkan sertifikat Syari'ah 


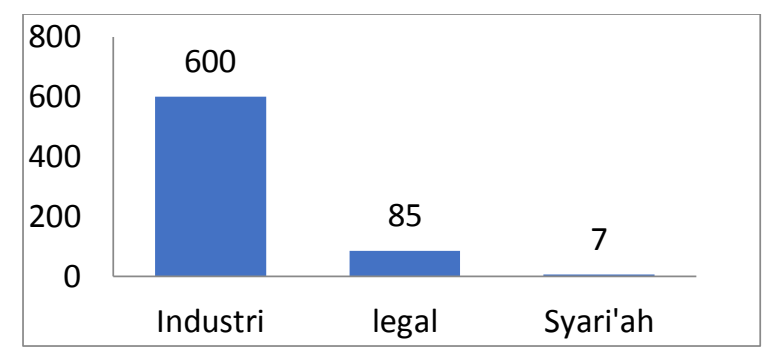

Gambar 1. Perbandingan Industri, Legal, dan Berbasis Syariah

(Sumber APLI, 2017)

Berikut adalah daftar perusahaan yang menapat sertifikat DSN MUI:

Tabel 1. Lembaga sertifikasi system syariah DSN MUI

(sumber Website DSN MUI, 2017)

\begin{tabular}{|c|c|c|c|}
\hline NO & LEMBAGA & PRODUK & $\begin{array}{c}\text { NO SURAT } \\
\text { KEPUTUSAN }\end{array}$ \\
\hline 1 & $\begin{array}{l}\text { PT Veritra Sentosa } \\
\text { Internasional }\end{array}$ & $\begin{array}{l}\text { Layanan } \\
\text { Pembayara } \\
\text { Multiguna }\end{array}$ & $\begin{array}{l}\text { 010.57.01/DSN- } \\
\text { MUI/VIII/2017 }\end{array}$ \\
\hline 2 & $\begin{array}{l}\text { PT Momen Global } \\
\text { Internasional }\end{array}$ & Nutrisi Kesehatan & $\begin{array}{l}\text { 006.53.01/DSN- } \\
\text { MUI/VII/2017 }\end{array}$ \\
\hline 3 & $\begin{array}{l}\text { PT UFO Bisnis } \\
\text { Kemitraan Bersama } \\
\text { Syariah }\end{array}$ & $\begin{array}{l}\text { Produk } \\
\text { Kesehatan }\end{array}$ & $\begin{array}{l}\text { 003.50.01/DSN- } \\
\mathrm{MUI} / \mathrm{I} / 2017\end{array}$ \\
\hline 4 & PT K-Link Nusantara & $\begin{array}{l}\text { Produk } \\
\text { Kesehatan }\end{array}$ & $\begin{array}{l}\text { 002.49.01/DSN- } \\
\text { MUI/I/2017 }\end{array}$ \\
\hline 5 & $\begin{array}{l}\text { PT Nusantara Sukses } \\
\text { Selalu }\end{array}$ & $\begin{array}{l}\text { Produk } \\
\text { Kesehatan }\end{array}$ & $\begin{array}{l}\text { 003.40.01/DSN- } \\
\text { MUI/III/2016 }\end{array}$ \\
\hline 6 & $\begin{array}{l}\text { PT Singa Langit Jaya } \\
\text { (TIENS) }\end{array}$ & $\begin{array}{l}\text { Produk } \\
\text { Kesehatan }\end{array}$ & $\begin{array}{l}\text { 003.38.01/DSN- } \\
\text { MUI/II/2016 }\end{array}$ \\
\hline 7 & PT HPA Indonesia & $\begin{array}{l}\text { Produk } \\
\text { Kesehatan }\end{array}$ & $\begin{array}{l}\text { 002.36.01/DSN- } \\
\text { MUI/IV/2015 }\end{array}$ \\
\hline
\end{tabular}

Fenomena money game, muncul dari perilaku yang dipilih oleh seseorang dalam mencari penghasilan. Azjen (2012) menjelaskan mengenai perilaku manusia, berdasarkan teori Planned behavior perilaku manusia didasari oleh 3 pertimbangan yakni Attitude toward the behavior (sikap) yang merupakan keseluruhan evaluasi seseorang mengenai positif atau negatifnya untuk menampilkan suatu perilaku tertentu, Subjective norm (norma subjektif) yang merupakan kepercayaan seseorang mengenai tuntutan dari orang lain yang dianggap penting baginya untuk bersedia menampilkan atau tidak menampilkan suatu perilaku tertentu sesuai dengan tuntutan dan Perceived behavioral control (pengendalian diri) yang merupakan persepsi seseorang tentang kemampuannya untuk menampilkan suatu perilaku tertentu. Penelitian ini bertujuan untuk menganalisis pengaruh sikap, norma subjektif, dan pengendalian diri terhadap 
intensi agen dalam memasarkan produk halal mart.

Konsep yang digunakan Halalmart adalah dengan menggunakan Multilevel marketing, Harefa (1999) mengungkapkan secara Etimologi Multi Level marketing (MLM) berasal dari bahasa Inggris, Multi berarti banyak sedangkan Level berarti jenjang atau tingkat sedangkan Marketing berarti pemasaran. Jadi dari kata tersebut dapat difahami bahwa MLM adalah pemasaran yang berjenjang banyak. Harefa (1999) memberikan penjelasan bahwa MLM adalah menjual atau memasarkan langsung suatu produk baik berupa barang atau jasa konsumen sehingga biaya distribusi dari barang yang dijual atau dipasarkan tersebut sangat minim bahkan sampai ke titik nol, yang artinya bahwa dalam bisnis MLM ini tidak diperlukan biaya distribusi

Arum (2014) menjelaskan bahwa perusahaan MLM Syariah adalah perusahaan yang menerapkan skema pemasaran modern melalui jaringan distribusi yang berjenjang, dengan menggunakan konsep syariah, baik dari skemanya maupun produk yang dijual..

Dewan Syariah Nasional (DSN) Majelis Ulama Indonesia telah mengeluarkan fatwa tentang MLM Syariah yang disebut dengan at- Taswiq Asy-Syabakiy, atau Penjualan Langsung Berjenjang Syariah (PLBS) dalam Fatwa DSN No. 75 tahun 2009

\subsection{Theory Planned Behaviour}

Menurut teori yang dikemukakan, Ajzen ( 2006) mengungkapkan bahwa perilaku manusia dipandu oleh 3 jenis pertimbangan yakni :

a. sikap, merupakan keseluruhan evaluasi seseorang mengenai positif atau negatifnya untuk menampilkan suatu perilaku tertentu.

b. Norma Subjektif, merupakan kepercayaan seseorang mengenai tuntutan dari orang lain yang dianggap penting baginya untuk bersedia menampilkan atau tidak menampilkan suatu perilaku tertentu sesuai dengan tuntutan

c. Pengendalian diri adalah persepsi seseorang tentang kemampuannya untuk menampilkan suatu perilaku tertentu

Sistem MLM dalam literatur fiqh termasuk dalam kategori muamalah yang dibahas dalam bab Al-Buyu' (Jual-Beli). Perusahaan yang menjalankan bisnisnya dengan sistem MLM selain melakukan penjualan produk barang juga melakukan penjualan produk jasa. Jasa penjualan ini (makelar) dalam terminologi fiqh disebut sebagai "Samsarah/simsar" Sayyid Sabiq dalam kitab Fiqh Sunnah menjelaskan pendapat para ulama seperti Ibnu Abbas, Imam Bukhari, Ibnu Sirin, Atha dan Ibrahim memandang boleh jasa ini. Untuk sahnya pekerjaan sebagai samsarah harus memenuhi beberapa syarat di antaranya :

1. Adanya Perjanjian yang jelas antara kedua belah pihak. 
2. Objek akad bisa diketahui manfaatnya secara nyata dan dapat diserahkan.

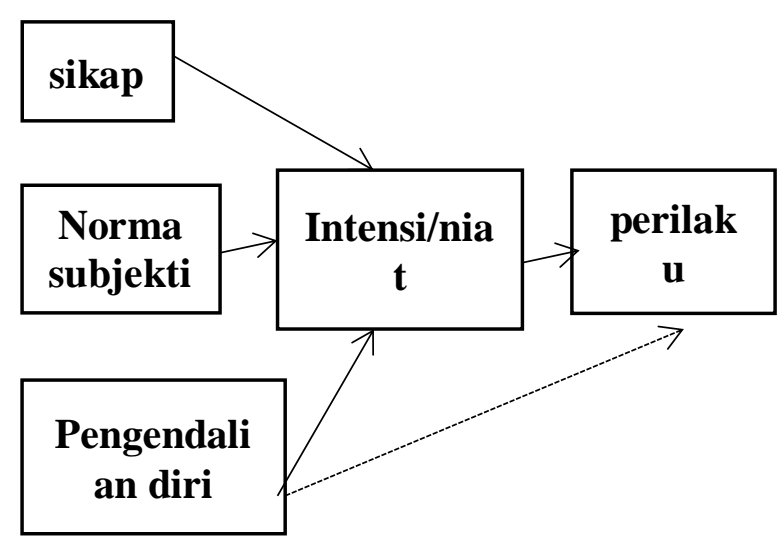

Putri (2018) dalam penelitianny mengungkapkan strategi promosi MLM syariah dan labelisasi halal berpengaruh terhadap keputusan pembelian.Rochmach (2018) dalam jurnalnya menjabarkan bahwa sikap merupakan hal mempunyai pengaruh yang dominan dalam menentukan pasien melakukan operasi.

Nuraini (2016) dalam jurnalnya mempublikasikan bahwa sikap terhadap kualitas siaran pers berpengaruh kuat terhadap niat penggunaan siaran pers. Amelia R, Hafidhuddin D, Tanjung H (2013) mempublikasikan persepsi jurnalis televisi terhadap perkembangan bank syariah di Indonesia dipengaruhi oleh variabel norma subjektif (SN) dan persepsi kontrol keperilakuan (PBC)

\section{METODE PENELITIAN}

Penelitian ini menggunakan metode theory of planned behavior (TPB) yang terintegrasi dengan variabel laten eksogen/variabel bebas yang digunakan, yakni sikap, norma subjektif
3. Objek akad bukan hal-hal yang diharamkan dan maksiat
, dan pengendalian diri dengan 20 indikator yang diamati .

Populasi yang di ambil adalah 300 agen Halalmart HNI HPAI di wilayah Kabupaten Karawang, Kota Bekasi dan Kabupaten Bekasi, dalam penelitian ini sampel sebanyak 75 responden. Dari sebaran 300 kuesioner, kurang lebih sebanyak 200 kuesioner yang dapat diolah sebagai bahan untuk pengolahan penelitian. Teknik pengambilan sampel yang akan digunakan dalam penelitian ini menggunakan teknik nonprobability sampling yaitu sampling accidental.

Analisis data dalam penelitian ini menggunakan metode PLS-SEM PLS merupakan pendekatan alternatif yang bergeser dari pendekatan SEM berbasis covariance menjadi berbasis varian (Ghozali 2008). SEM yang berbasis kovarian umumnya menguji kausalitas sedangkan PLS lebih bersifat predictive model. Penelitian ini menggunakan Software SmartPLS 3.0 
Dalam PLS Path Modeling terdapat 2 Kuesioner yang disebar berjumlah 300, model yaitu outer model dan Inner model. disebarkan kepada 6 bisnis center Halalmart Outer model (outer relation/measurement yakni BC Karawang 1, BC Karawang 2,BC model) menunjukkan spesifikasi hubungan Karawang 3, BC Karawang 4, BC Mustika antar variabel dengan indikatornya, Jaya, BC Cikarang Barat, BC Tambun dalam sedangkan inner model (inner kurun waktu 7 bulan yakni dari bulan februari relation/structural model) menunjukkan sampai september 2019. Yang dapat diolah spesifikasi hubungan antar variabel laten, menjadi bahan penelitian sebanyak 200 yaitu antara variabel eksogen/independen kuesioner dengan variabel endogen/dependen (Ghozali, 2008).

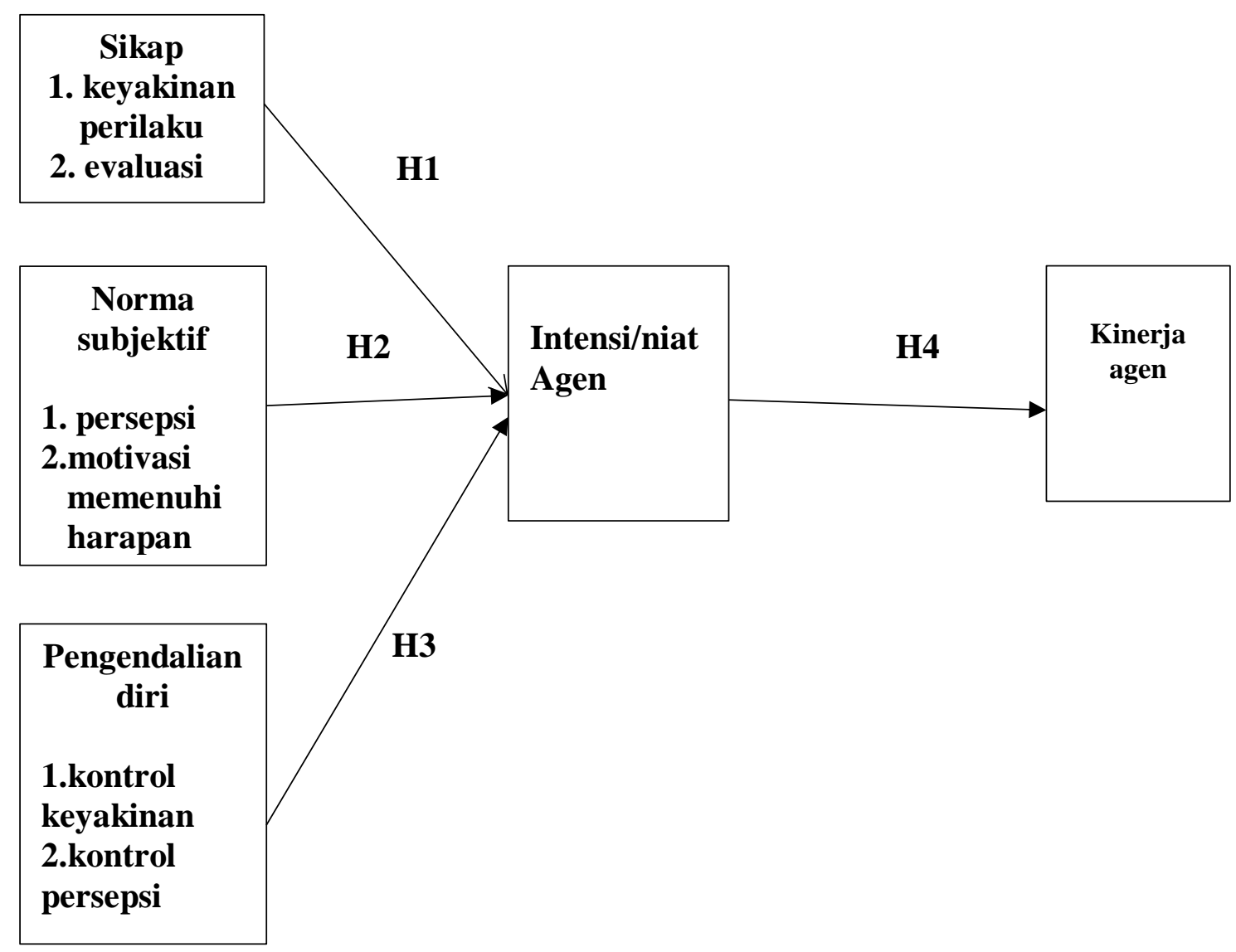




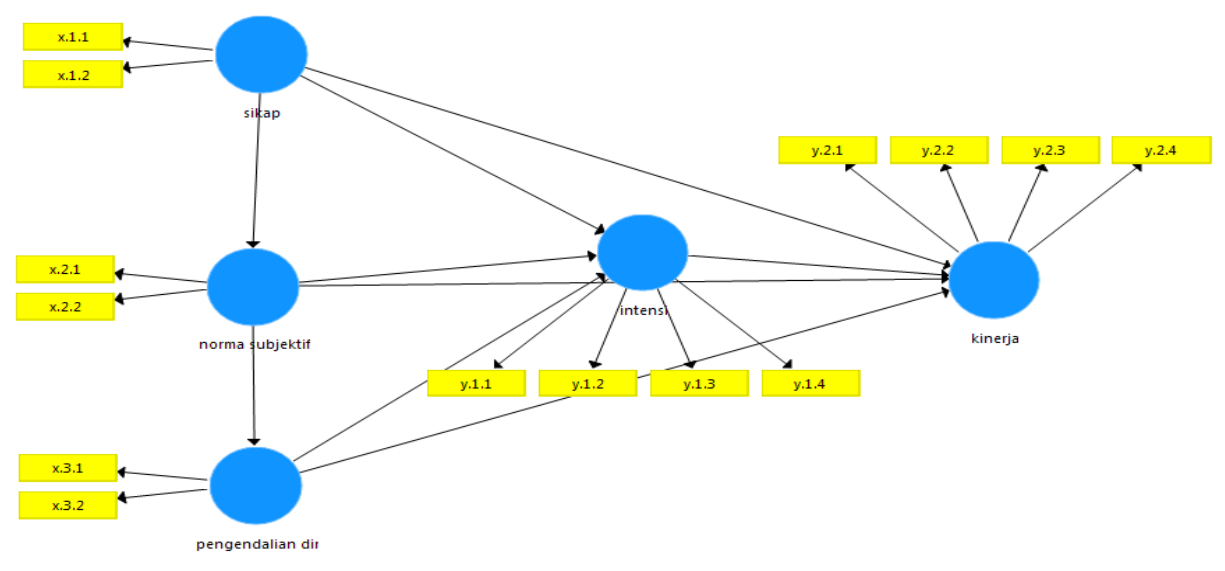

Dilihat dari jenis kelamin, prosentase harus lebih besar dari nilai korelasi antar responden laki-laki berjumlah $45 \%$ dan variabel, sedangkan cross loading setiap prosentase perempuan berjumlah 55\%. indikator harus memiliki loading lebih tinggi Mayoritas responden sudah memasarkan untuk setiap variabel laten yang diukur, produk halalmart 2-5 tahun dan dibandingkan dengan indikator untuk variabel berpenghasilan Rp 1.500.001 sampai dengan laten lainnya.

Rp 3.000.000 dari bonus memasarkan produk

Dari konstruksi convergen laten ada Halalmart.

\subsection{Hasil Evaluasi Measurement Model (Model Pengukuran/Outer Model)} beberapa indikator pembentuk variable yang nilainya dibawah 0,6. Menurut hair (20018), jika koefisien atau loading factor dari masing-

Ghozali (2006) menyatakan bahwa analisis outer model menggunakan lima kriteria yaitu convergent validity, composite reliability, average variance extracted (AVE).

Model dinyatakan baik apabila memiliki indikator dengan nilai loading factor yang lebih besar dari 0,6. Konsistensi internal dari Composite reliability dengan standar nilai di atas 0,6. validitas konstruk dari AVE menunjukkan dengan standar nilai lebih besar dari 0,5, sedangkan AVE kuadrat dan cross loading menunjukkan validitas diskriminan di mana nilai standar untuk akar kuadrat AVE masing indikator pada model kurang dari 0,6 maka harus direduksi untuk menghasilkan model pengukuran yang baik. Proses reduksi dilakukan hingga seluruh indikator memiliki loading factor lebih dari 0,6.

Pada kriteria composite reliability, diketahui bahwa seluruh variabel laten yang digunakan dalam penelitian ini telah memiliki nilai lebih besar dari standar 0,6.. Pada kriteria cronbach alpha, diketahui bahwa hampir seluruh variabel mempunyai nilai cronbach alpha lebih besar dari 0,7 hanya variabel norma subjektif dan pengendalian 
diri yang kurang dari 0,7. Hal ini menunjukkan bahwa indikator masih dapat mengukur variabel (reliabel).

Pada kriteria AVE, dapat dilihat bahwa seluruh variabel laten memiliki nilai lebih dari 0,5 yang berarti variabel tersebut memenuhi syarat uji validitas konstruk.. Berdasarkan empat kriteria (Ghozali,2006) kriteria tersebut, maka dapat disimpulkan bawah model pengaruh sikap, norma subjektif dan pengendalian diri terhadap intensi dan kinerja yang dibuat telah memenuhi syarat model yang baik, sehingga dapat dilanjutkan untuk

\begin{tabular}{|c|c|c|c|}
\hline No & Kriteria & Standar & Hasil penilaian \\
\hline 1 & $\begin{array}{l}\text { Loading Factor } \\
\text { (Convergent Validity }\end{array}$ & $\geq 0,6$ & Terdapat variabel yang dibawah 0,6 \\
\hline 2 & Composite Reliability & $>0,6$ & $\begin{array}{ll}\text { Intensi } & : 0,863 \\
\text { Kinerja } & : 0.882 \\
\text { Norma subjektif } & : 0.778 \\
\text { Pengendalian diri } & : 0.716 \\
\text { Sikap } & : 0.844\end{array}$ \\
\hline 3 & Cronbach Alpha & $>0,7$ & $\begin{array}{lr}\text { Intensi } & : 0.789 \\
\text { Kinerja } & : 0.819 \\
\text { Norma subjektif } & : 0.497 \\
\text { Pengendalian diri } & : 0.241 \\
\text { Sikap } & : 0.752\end{array}$ \\
\hline 4 & AVE & $>0,5$ & $\begin{array}{ll}\text { Intensi } & : 0.616 \\
\text { Kinerja } & : 0.652 \\
\text { Norma subjektif } & : 0.644 \\
\text { Pengendalian diri } & : 0.564 \\
\text { Sikap } & : 0.576\end{array}$ \\
\hline
\end{tabular}

Dari konstruksi convergen laten ada beberapa indikator pembentuk variable yang nilainya dibawah 0,6. Menurut hair (20018), jika koefisien atau loading factor dari masingmasing indikator pada model kurang dari 0,6 maka harus direduksi untuk menghasilkan model pengukuran yang baik. Proses reduksi dilakukan hingga seluruh indikator memiliki loading factor lebih dari 0,6. Pada kriteria composite reliability, diketahui bahwa seluruh variabel laten yang digunakan dalam penelitian ini telah memiliki nilai lebih besar dari standar 0,6. Hal ini menunjukan bahwa semua variabel yang digunakan dalam penelitian mampu menjelaskan kondisi yang ingin diketahui melalui model niat dan kinerja agen secara konsisten. Pada kriteria cronbach alpha, diketahui bahwa hampir seluruh variabel mempunyai nilai cronbach alpha lebih besar dari 0,7 hanya variabel norma subjektif dan pengendalian diri yang kurang dari 0,7. Hal ini menunjukkan bahwa indikator masih dapat mengukur variabel (reliabel). 
Pada kriteria AVE, dapat dilihat untuk dilakukan pengolahan untuk tahap bahwa seluruh variabel laten memiliki nilai berikutnya.

lebih dari 0,5 yang berarti variabel tersebut Model awal dan akhir intensi dan kinerja memenuhi syarat uji validitas konstruk.. agen, dapat dilihat pada Gambar 5 dan Berdasarkan empat kriteria (Ghozali,2006) Gambar 6. Berdasarkan Gambar 5 dan 6 kriteria tersebut, maka dapat disimpulkan diketahui bahwa terdapat beberapa indikator bawah model pengaruh sikap, norma subjektif yang harus direduksi karena kurang dan pengendalian diri terhadap intensi dan memenuhi kriteria $(<0,7)$. Indikator-indikator kinerja yang dibuat telah memenuhi syarat yang direduksi dari ketiga model secara model yang baik, sehingga dapat dilanjutkan lengkap dapat dilihat pada Tabel 3

Tabel 3 Indikator-indikator yang harus direduksi dari model

\begin{tabular}{llllll}
\hline \multicolumn{2}{c}{ Sikap } & \multicolumn{2}{c}{ Norma Subjektif } & \multicolumn{2}{c}{ Pengendalian Diri } \\
\hline Indikator & $\begin{array}{l}\text { loading } \\
\text { faktor }\end{array}$ & indikator & $\begin{array}{l}\text { loading } \\
\text { faktor }\end{array}$ & indikator & $\begin{array}{l}\text { loading } \\
\text { faktor }\end{array}$ \\
\hline $\begin{array}{l}\text { kj04 -> } \\
\text { sikap }\end{array}$ & $\mathbf{0 . 4 5 1}$ & $\begin{array}{l}\text { kj07 -> } \\
\text { Norma } \\
\text { subjektif }\end{array}$ & $\mathbf{0 , 0 8 6}$ & $\begin{array}{l}\text { kj11 -> } \\
\text { Pengendalian }\end{array}$ & $\mathbf{0 , 5 1 7}$ \\
kj06 - & $\mathbf{- 0 , 1 3 4}$ & & & & \\
diri & & \\
\hline sikap & & & & & \\
\hline
\end{tabular}

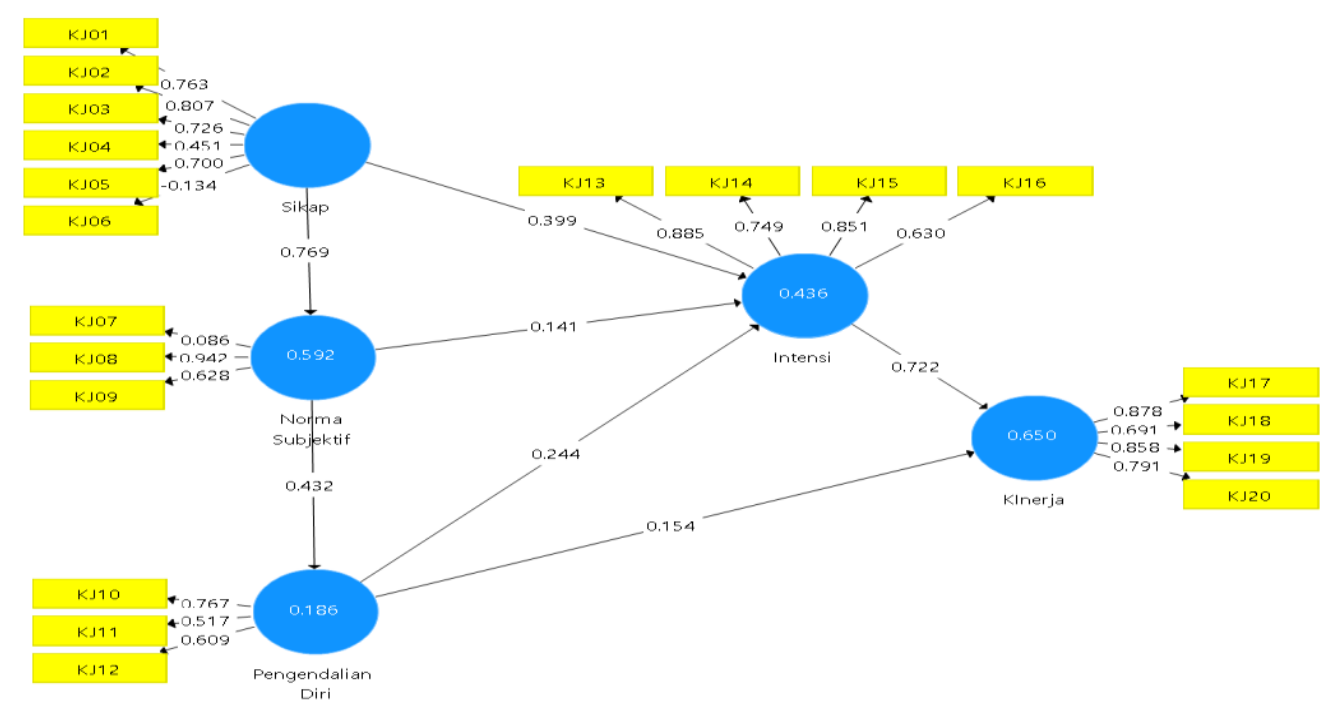

Gambar 5 model awal intensi dan kinerja agen 


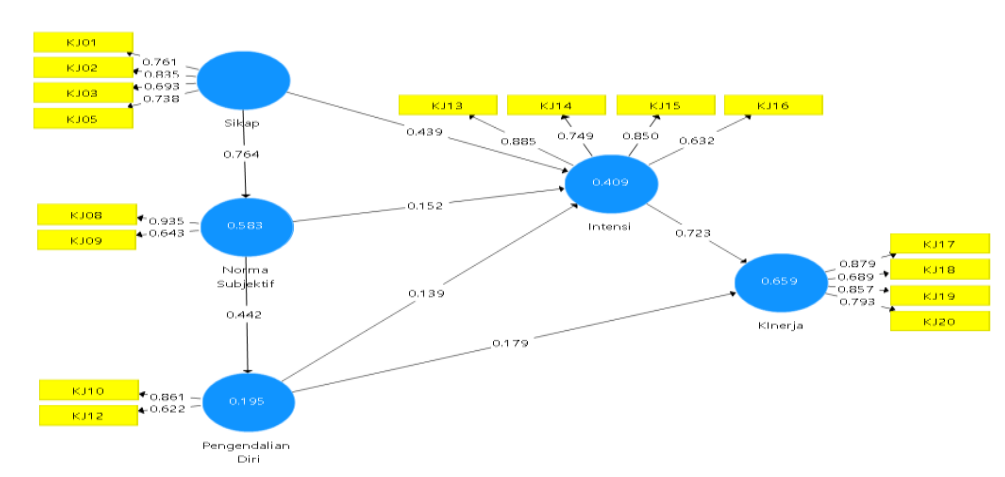

Gambar 6. Model akhir intensi dan kinerja agen

Tabel 4. Indikator model intensi dan kinerja dengan nilai loading factor yang memenuhi kriteria

Setiap variabel laten memiliki indikator terbesar merupakan faktor yang dianggap utama yang memiliki loading factor terbesar, paling penting oleh agen dalam penguatan yaitu indikator yang paling merefleksikan intensi dan kinerja. Tabel 5 menunjukkan variabel latennya. Hal ini berarti dari variabel kekuatan indikator merefleksikan variabel laten yang memiliki nilai loading factor dalam model.

Table 5. Nilai loading factor tertinggi interelasi refleksi indicator

\begin{tabular}{|l|r|l|l|l|l|l|r|r|r|}
\hline \multicolumn{2}{|c|}{ Sikap } & \multicolumn{2}{c|}{ Norma Subjektif } & \multicolumn{2}{c|}{ Pengendalian Diri } & \multicolumn{3}{c|}{ Intensi } & \multicolumn{2}{c|}{ Kinerja } \\
\hline indikator & $\begin{array}{l}\text { loading } \\
\text { faktor }\end{array}$ & Indikator & $\begin{array}{l}\text { loading } \\
\text { faktor }\end{array}$ & indikator & $\begin{array}{l}\text { loading } \\
\text { faktor }\end{array}$ & indikator & $\begin{array}{l}\text { loading } \\
\text { faktor }\end{array}$ & indikator & $\begin{array}{l}\text { loading } \\
\text { faktor }\end{array}$ \\
\hline kj01 & $\mathbf{0 . 7 6 3}$ & kj08 & 0.942 & kj10 & 0.767 & kj13 & 0.885 & kj17 & 0.878 \\
\hline kj02 & 0.807 & kj09 & 0.628 & kj12 & 0.609 & kj14 & 0.749 & kj18 & 0.691 \\
\hline kj03 & 0.726 & & & & & kj15 & 0.851 & kj19 & 0.858 \\
\hline kj05 & 0.7 & & & & & kj16 & 0.63 & kj20 & 0.791 \\
\hline
\end{tabular}




\begin{tabular}{|c|l|r|}
\hline \multicolumn{2}{|c|}{ Variabel Laten } & \multicolumn{2}{|c|}{ Hasil Perhitungan } \\
\hline sikap & Indikator & $\begin{array}{l}\text { Loading } \\
\text { Factor }\end{array}$ \\
\hline norma subjektif & kj02 & $\mathbf{0 . 8 0 7}$ \\
\hline pengendalian diri & kj08 & $\mathbf{0 . 9 4 2}$ \\
\hline intensi & kj10 & $\mathbf{0 . 7 6 7}$ \\
\hline kinerja & kj13 & $\mathbf{0 . 8 8 5}$ \\
\hline & kj17 & $\mathbf{0 . 8 7 8}$ \\
\hline
\end{tabular}

Tabel 4. Indikator model intensi dan kinerja dengan nilai loading factor yang memenuhi kriteria

Dapat diketahui berdasarkan Tabel 5 bahwa pada model gabungan indikator yang paling merefleksikan variabel Sikap adalah indikator KJ02, yaitu keyakinan seorang agen menjual produk HNI. Hal ini menunjukan bahwa seorang agen memiliki keyakinan yang signifikan dalam memasarkan produk. Pada variabel norma subjektif, indikator yang paling merefleksikan adalah indikator KJ08, yaitu Inspirasi Leader (KJ8). Hal ini menunjukan bahwa seorang leader yang sukses memberikan dorongan intensi dan berdampak pada kinerja para agen.

Pada variabel pengendalian diri, indikator yang paling merefleksikan adalah indikator KJ10, yaitu semangat agen dalam menjualkan produk. Hal ini menunjukan bahwa semangat dari dalam pribadi berdampak kuat pada kinerja agen. Pada variabel intensi indikator yang paling merefleksikan adalah indikator KJ13, yaitu
Semangat penjualan produk ketika stok kosong (KJ 13). Hal ini menunjukan bahwa semangat dalam diri memberikan dampak yang kuat untuk intensi para agen untuk memasarkan. Pada variabel kinerja indikator yang paling merefleksikan adalah indikator KJ17, yaitu Perasaan bahagia menjual produk. Hal ini menunjukan bahwa para agen mempunyai perasaan bahagia dalam memasarkan produk.

\subsection{Hasil Evaluasi Model Struktural (Inner Model)}

Inner model adalah model struktural yang menghubungkan antar variabel laten pada substantif teori yakni variabel eksogen terhadap variabel endogen.

Untuk menguji pengaruh secara parsial variabel eksogen $(\mathrm{X})$ terhadap variabel endogen (Y) dapat digunakan melalui Uji hipotesis dengan melihat nilai t-values pada masing-masing path. Nilai t-statistik dapat 
diperoleh dari hasil bootstrapping dengan struktural dapat dikatakan signifikan dengan Software Smart-PLS. Pengujian melalui syarat nilai t-statistik > dari t-tabel yakni bootstrap bertujuan untuk meminimalkan sebesar 1,96 dengan tingkat keyakinan 95\%. masalah ketidaknormalan data penelitian. Hasil uji t-statistik dan uji hipotesis dapat nilai koefisien inner weight dari model dilihat pada tabel 6

\begin{tabular}{|c|c|c|c|}
\hline & $\begin{array}{l}\text { Original } \\
\text { Sample (O) }\end{array}$ & $\begin{array}{l}\text { T Statistics } \\
(|\mathrm{O} / \mathrm{STDEV}|)\end{array}$ & Signifikansi \\
\hline Intensi -> KInerja & 0.723 & 21.141 & Signifikan \\
\hline $\begin{array}{l}\text { Norma Subjektif -> } \\
\text { Intensi }\end{array}$ & 0.152 & 2.183 & Signifikan \\
\hline $\begin{array}{l}\text { Norma Subjektif -> } \\
\text { Pengendalian Diri }\end{array}$ & 0.442 & 7.631 & Signifikan \\
\hline $\begin{array}{l}\text { Pengendalian Diri -> } \\
\text { Intensi }\end{array}$ & 0.139 & 2.621 & Signifikan \\
\hline $\begin{array}{l}\text { Pengendalian Diri -> } \\
\text { KInerja }\end{array}$ & 0.179 & 3.862 & Signifikan \\
\hline Sikap -> Intensi & 0.439 & 5.881 & Signifikan \\
\hline Sikap -> Norma Subjektif & 0.764 & 18.441 & Signifikan \\
\hline
\end{tabular}

Tabel 6. Hasil path coeffisien model

Rule of tumbs dari terdukungnya suatu sikap berpengaruh terhadap orientasi norma hipotesis penelitian adalah : (1) jika koefisien subjektif, orientasi norma subjektif atau arah hubungan variable (ditunjukan oleh berpengaruh terhadap pengendali diri, nilai original sample) sejalan dengan yang orientasi pengendalu diri berpengaruh dihipotesiskan, dan (2) jika nilai t statistic terhadap intensi. Orientasi intensi lebih dari 1,96 dan probability value (p-value) berpengaruh terhadap terhadap kinerja, kurang dari 0,05 atau 5\%. Maka hasil uji adapun hasil uji hipotesis disajikan dalam statistic yang mendukung hipotesis adalah tabel 7. Dibawah ini :

\begin{tabular}{|l|l|l|l|}
\hline Hipotesis & $\begin{array}{l}\text { t- } \\
\text { statistic }\end{array}$ & $\begin{array}{l}\text { t-table } \\
\text { sig } \\
95 \%\end{array}$ & Hasil \\
\hline $\begin{array}{l}\text { Norma Subjektif } \\
\text { berpengaruh } \\
\text { positif dan } \\
\text { signifikan } \\
\text { terhadap Intensi }\end{array}$ & $\mathbf{2 , 8 3}$ & 1,96 & Diterima \\
\hline $\begin{array}{l}\text { Norma Subjektif } \\
\text { berpengaruh } \\
\text { positif dan } \\
\text { signifikan }\end{array}$ & 7,631 & 1,96 & Diterima \\
\hline
\end{tabular}




\begin{tabular}{|l|l|l|l|}
\hline $\begin{array}{l}\text { terhadap } \\
\text { Pengendalian } \\
\text { Diri }\end{array}$ & & & \\
\hline $\begin{array}{l}\text { Pengendalian } \\
\text { Diri berpengaruh } \\
\text { positif dan } \\
\text { signifikan } \\
\text { terhadap Intensi }\end{array}$ & $\mathbf{2 , 6 2 1}$ & $\mathbf{1 , 9 6}$ & Diterima \\
\hline $\begin{array}{l}\text { Pengendalian } \\
\text { Diri berpengaruh } \\
\text { positif dan } \\
\text { Signifikan } \\
\text { terhadap Kinerja }\end{array}$ & $\mathbf{3 , 8 6 2}$ & $\mathbf{1 , 9 6}$ & Dterima \\
\hline $\begin{array}{l}\text { Sikap } \\
\text { berpengaruh } \\
\text { positif dan } \\
\text { signifikan } \\
\text { terhadap Intensi }\end{array}$ & $\mathbf{5 , 8 8 1}$ & $\mathbf{1 , 9 6}$ & Diterima \\
\hline $\begin{array}{l}\text { Sikap } \\
\text { berpengaruh } \\
\text { positif dan } \\
\text { signifikan } \\
\text { terhadap Norma } \\
\text { Subjektif }\end{array}$ & $\mathbf{1 8 , 4 4 1}$ & $\mathbf{1 , 9 6}$ & Diterima \\
\hline
\end{tabular}

H0: variabel Intensi tidak berpengaruh signifikan terhadap variabel Kinerja

H1: variabel Intensi berpengaruh signifikan terhadap variabel Kinerja

Berdasarkan Pada tabel di atas nilai $\mathrm{t}$ stat $=21.141>1.96$ sehingga H0 ditolak, dan diterima $\mathrm{H} 1$, yang berarti variabel Intensi berpengaruh positif dan signifikan terhadap variabel Kinerja. Makin tinggi Intensi, makin tinggi Kinerja demikian juga sebaliknya 4.3 Hasil Koefisien Determinasi (R-square)

Menurut Chin (1998), standar R square, standar nilai $\mathrm{R}$ square 0.67 kategori kuat, 0.33 moderat, dan 0.19 lemah. Pada persamaan pertama dimana pengaruh sikap terhadap norma subjektif memiliki nilai $\mathrm{R}$
Square sebesar 0.583 mendekati kategori kuat . Hal ini berarti model dari penelitian norma subjektif dapat dijelaskan oleh independen variabel yaitu sikap sebesar 58,3\%. Sedangkan sisanya $41,7 \%$ dijelaskan oleh variabel lain diluar dari model yang diteliti.

Pada persamaan kedua dimana pengaruh sikap dan norma subjektif terhadap pengendalian diri memiliki nilai $\mathrm{R}$ Square sebesar 0.195, termasuk dalam kategori lemah. Hal ini berarti model dari penelitian norma pengendalian diri dapat dijelaskan oleh independen variabel yaitu sikap sebesar $19,5 \%$. Sedangkan sisanya $80,5 \%$ dijelaskan oleh variabel lain diluar dari model yang diteliti. 
Pada persamaan ketiga dimana pengaruh sikap,

norma subjektif,pengendalian diri terhadap intensi memiliki nilai R Square sebesar 0.409, termasuk dalam kategori moderat. Hal ini berarti model dari penelitian intensi dapat dijelaskan oleh independen variabel yaitu sikap sebesar 40,9\%. Sedangkan sisanya $59,1 \%$ dijelaskan oleh variabel lain diluar dari model yang diteliti.

Pada persamaan keempat dimana pengaruh sikap, norma subjektif, pengendalian diri, intensi terhadap kinerja memiliki nilai $\mathrm{R}$ Square sebesar 0.659, termasuk dalam kategori kuat. Hal ini berarti model dari penelitian kinerjai dapat dijelaskan oleh independen variabel yaitu sikap sebesar $65,9 \%$. Sedangkan sisanya $34,1 \%$ dijelaskan oleh variabel lain diluar dari model yang diteliti Tabel 8. Hasil Koefisien Daterminasi (R-Square)

\begin{tabular}{|l|l|}
\hline & \multicolumn{1}{|c|}{ R Square } \\
\hline Intensi & 0.409 \\
\hline Kinerja & 0.659 \\
\hline Norma Subjektif & 0.583 \\
\hline Pengendalian Diri & 0.195 \\
\hline & \\
\hline
\end{tabular}

\section{SIMPULAN}

Berdasarkan penelitian dan pembahasan, sikap mempunyai pengaruh sigifikan dan positif terhadap Intensi agen memiliki sikap mempunyai kemauan kuat untuk menjalani bisnis. Hubungan norma subjektif terhadap intensi mempunyai hubungan yang positif dimana kegiatan yang menginspirasi dari seorang agen yang telah berhasil (leader sukses) merupakan indikator penting untuk menumbuhkan intensi. Pengaruh pengendali diri terhadap intensi mempunyai hubungan yang positif, dimana indicatornya yakni seorang agen tidak bosan dalam berjualan produk halamart merupakan variable yang membantu para agen menemukan strong why sehingga selalu bersemangat dan berbahagia menjalani aktivitasnya sebagai agen halalmart..

Penelitian berguna untuk agen dan manajemen dengan diadakannya pelatihan secara berkala di 1 tahun pertama dalam menjalankan bisnis HNI dimana didalamnya menggugah semangat berjuang untuk menghindarkan diri dan oranglain dari hal yang haram, inspirasi dari orang yang sudah sukses dan juga pengawalan untuk para agen untuk disiplin dalam pencapaian target khususnya di 1 tahun pertama.

\section{REFERENSI}

Ab Talib, M., Ai Chin, T. and Fischer, J. (2017), "Linking Halal food certification and business performance", British Food Journal, Vol. 119 No. 7, pp. 1606-1618

Ali, M., Raza, S. and Puah, C. (2017), "Factors affecting to select Islamic credit cards in Pakistan: the TRA model", Journal of Islamic Marketing, Vol. 8 No. 3, pp. 330-344. 
Ajzen, Icek. (2012), The theory of planned behavior, University of Massachusetts Amherst

Ajzen,Icek, (2006), Constructing TpB Questionnaire : conceptual and methodological consideration. September, 2002 (Revised January, 2006). Diunduh dari https://pdfs.semanticscholar.org/

Amelia R, Hafidhuddin D, Tanjung $\mathrm{H}$. (2014), Analysis Of Factors Affecting Television Journalist Perception On Islamic Banking Development In Indonesia, Jurnal Al-Muzara'ah, Vol. 2, No. 2

Aoun, I. and Tournois, L. (2015), "Building holistic brands: an exploratory study of Halal cosmetics", Journal of Islamic Marketing, Vol. 6 No. 1, pp. 109-132. https://doi.org/10.1108/JIMA-05-2014$\underline{0035}$

Arum, Imam Mas. (2013), ATTARBIYAH: Multi Level Marketing (MLM) Syariah :Solusi Praktis Menekan Praktik Bisnis Riba,Money Game, Journal of Islamic Culture and Education, Salatiga

Cahyani, Dewi Rina, .(2018), Transaksi Bisnis MLM Tembus Rp 15,75 Triliun, https://bisnis.tempo.co/read/1050063/tra nsaksi-bisnis-mlm-tembus-rp$\underline{1575 \text { triliun/full\&view }=\text { ok }}$

\section{Daftar Perusahaan Penjualan Langsung} Berjenjang Syariah. (2017), https://dsnmui.or.id/daftar-perusahaanpenjualan-langsung-berjenjang-syariah/

Differences in Direct Selling and Pyramid. 2016, https://www.apli.or.id/perbedaandirect-selling-dan-piramida/Gadded and Snehota. 2001, Rethinking the Role of Middlemen,

https://www.researchgate.net/publicatio n/237739014_Rethinking_the_Role_of_ Middlemen
Hair,Joe.risher,Jeffrey. Sarstedt,Marko. Ringle, Christian, (2018), when to use and how to report the result of PLS$S E M$, Emerald Publishing Limited

Iversen, V. and Torsvik, G. (2010),

"Networks, middlemen and other (urban) labour market mysteries", Indian Growth and Development Review, Vol. 3 No. 1, pp. 62-80. Emerald Group Publishing Limited

Kwong,Ken., \& Wong,Kay. (2013), Partial Least Squares Structural Equation Modelling (PLS-SEM) Techniques Using Smart PLS. Marketing Bulletin 2013,24,Technical Note 1

Mangkunegara, AA. Anwar Prabu. (2013), Manajemen Sumber Daya Manusia Perusahaan, Remaja Rosdakarya, Bandung

Mardatillah,Annisa. (2013), "Etika Bisnis Dalam Perspektif Islam, JIS Vol.6.No.1. April 2013 Mingka, Agustianto, http://www.agustiantocentre.com/?p 648

Multi Level Marketing Menurut Hukum Islam. (2013), http://www.iaeipusat.org/en/article/ekonomisyariah/multi-level-marketing-menuruthukum-islam-

Nuraini, Rahmi. (2016), implementasi teori planned behavior dalam penggunaan siaran pers oleh jurnalis, https://www.researchgate.net/publicatio n/317199789_Implementasi_Teori_Plan ned_Behaviour_Dalam_Penggunaan_Si aran_Pers_Oleh_Jurnalis

P,Szopa dan W, Pękała. (2012), Distribution Channels And Their Roles In The Enterprise, Polish Journal Of Management Studies 
Putri, Arinda Widiantika. (2018), Pengaruh Strategi Pemasaran Mlm Syariah Danlabelisasihalal Terhadap Keputusan Pembelian Konsumen (Studi Pada Agency Produk Herba Penawar Al wahida Indonesia Di Kabupaten Ponorogo).

http://etheses.iainponorogo.ac.id/4413

Rafiki, A. and Abdul Wahab, K. (2016),

"The human capital and the obtainment of halal certification", Journal of Islamic Marketing, Vol. 7 No. 2

Setiawan, Yuli dan Setyorini,Retno, (2015). Pengaruh Sikap,Norma Subjektif Dan Perceived Behavior Control (Pbc) Terhadap Intensi Membeli Produk Makanan Berlabel Halal Pada Masyarakat Desa Cipeujeuh kabupaten Bandung, e-Proceeding of Management : Vol.2, No.2 Agustus 2015 | Page 2088

Suki,Norazah Mohd and Salleh, Abang Sulaiman Abang, (2016) Does Halal image strengthen consumer intention to patronize Halal stores?: Some insights from Malaysia. Journal of Islamic Marketing, 7 (1). pp. 120-132. ISSN 1759-0833

Sutanto, Eddy Madiono dan Suwondo, Diah Indriani, (2015). Hubungan Lingkungan Kerja, Disiplin Kerja, Dan Kinerja Karyawan. Jurnal Manajemen Dan Kewirausahaan, Vol.17, No. 2, September 2015

Sutrisno, Edy. (2016). Manajemen Sumber Daya Manusia, Bandung: PT. Mulia Kencana Semesta

Tirmizi, Erwandi. (2017), Harta Haram Kontemporer, Bogor, BMI Publishing

Wahyudi,Firman. (2014), AL-BANJARI: Multi Level Marketing Dalam Kajian Fiqh Muamalah 